Rank $=1$

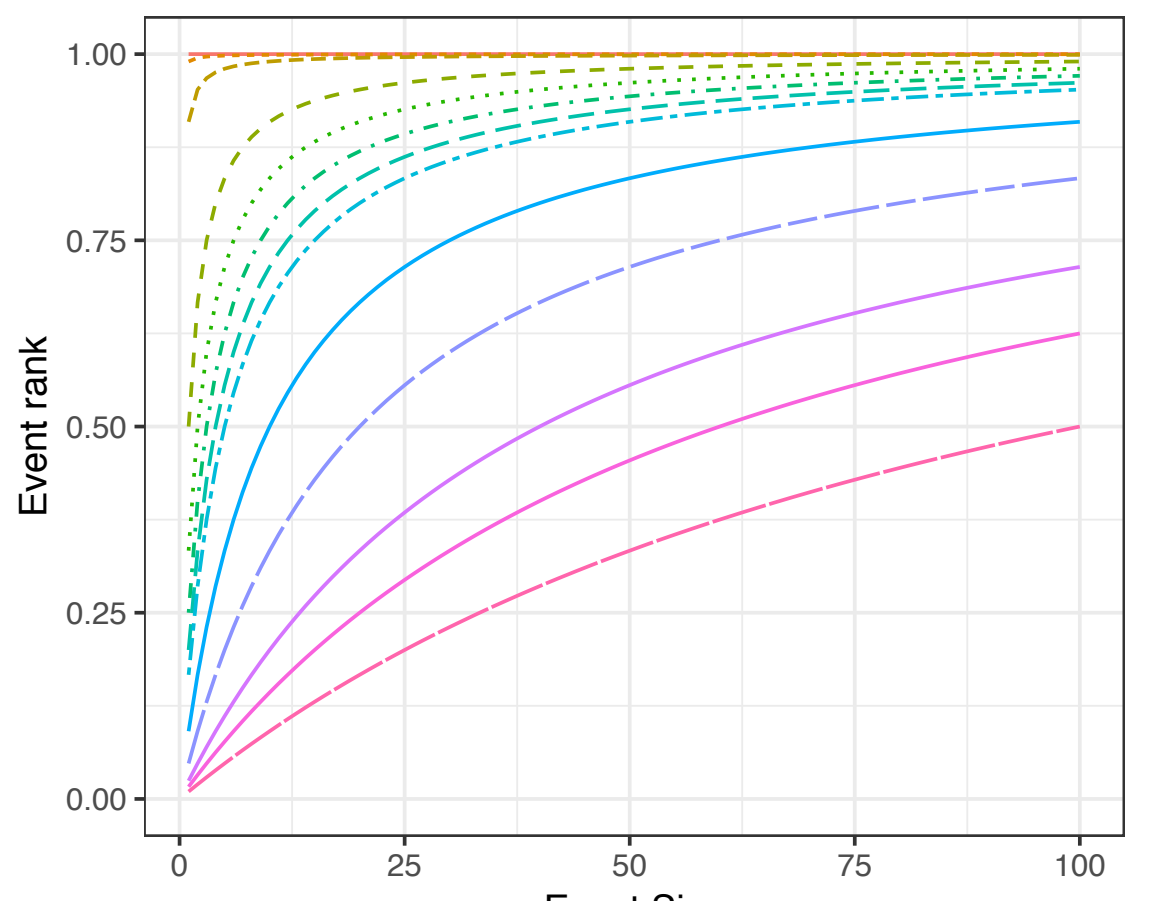

Event Size

Constant
-0
$-\cdot \cdot 0.01$
$--\cdot 0.1$
--1
$\cdots \cdot 2$
$-\cdot 3$
--4
--5
-10
-20
-40
-60
-100

Rank $=10$

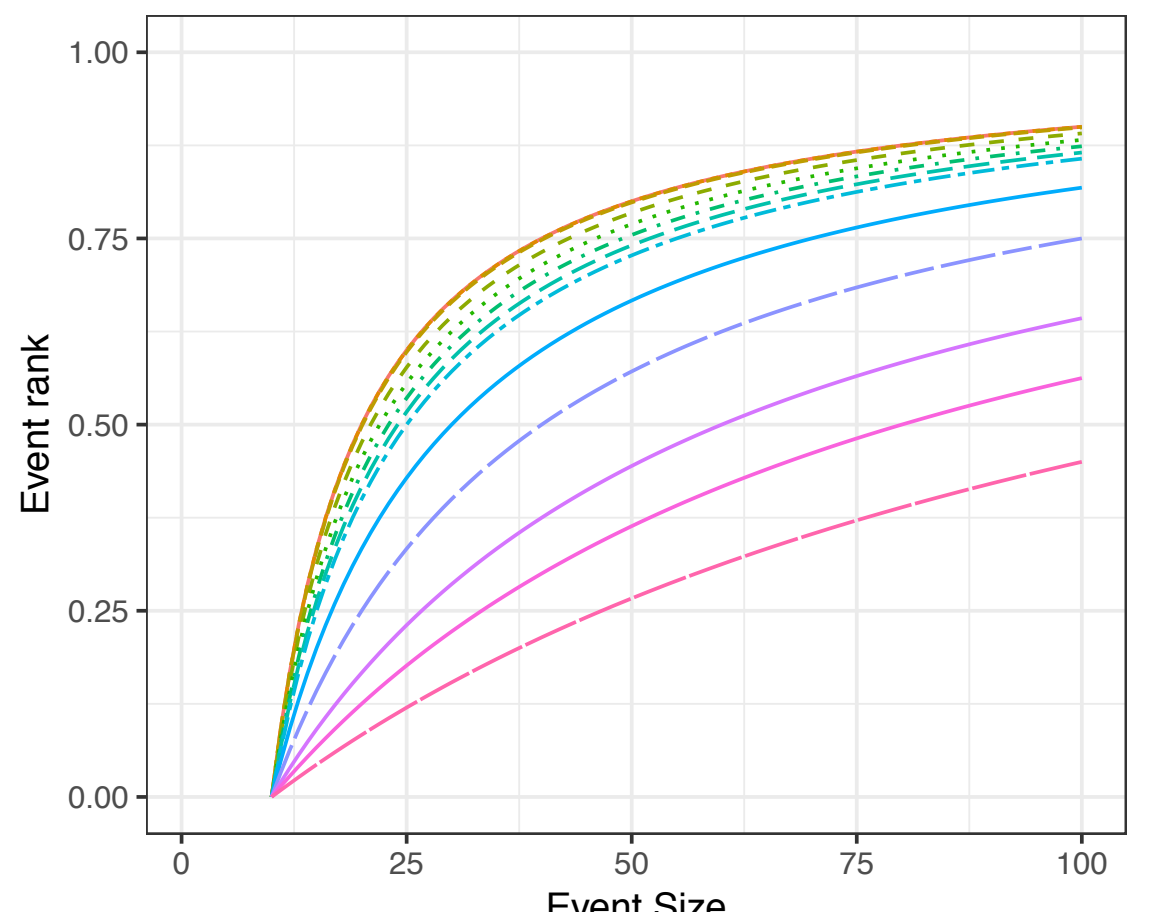

Constant C

$-0$

- - 0.01

--. 0.1

$--1$

…2 2

-. 3

$--4$

$--.5$

$-10$

$-20$

$-40$

- 60

$-100$

\section{Event Size}

